\title{
Basis of Contract Clause in the UK and the Necessity for Reforming Insurance Law in Iran
}

\author{
Abdolazim Khorooshi ${ }^{1}$, Habibollah Rahimi ${ }^{2}$, Abbas Ghasemi Hamed ${ }^{3} \&$ Jalil Maleki $^{4}$ \\ ${ }^{1} \mathrm{PhD}$ candidate of Private law, Department of Private Law, College of Law and Politics, Science and Research \\ Branch, Islamic Azad University, Tehran, Iran \\ ${ }^{2}$ Assistant Professor, Department of Private Law, College of Law and Politics, Allameh Tabataba'i University, \\ Tehran, Iran \\ ${ }^{3}$ Professor of Law, Department of Private Law, College of Law and Politics, Shahid Beheshti University, Tehran, \\ Iran \\ ${ }^{4}$ Assistant Professor, Department of Private Law, College of Law and Politics, Central Branch, Islamic Azad \\ University, Tehran, Iran \\ Correspondence: Habibollah Rahimi, Assistant Professor, Department of Private Law, College of Law and \\ Politics, Allameh Tabataba'i University, Tehran, Iran. E-mail: Rahimi@atu.ac.ir
}

Received: August 1, 2016

doi:10.5539/jpl.v10n2p156
Accepted: October 11, $2016 \quad$ Online Published: February 28, 2017

URL: https://doi.org/10.5539/jpl.v10n2p156

\begin{abstract}
In insurance, terms and conditions by insurers at the end of proposal forms or insurance contracts will be included in print that the insured has confirmed the authenticity of answer to questions and provided information, and agrees that the statements are "basis of contract". If an inaccuracy of those announcements proves later, insurer regardless of the importance of statements in acceptance of the risk or determination of the premium can disclaim based on this clause himself and avoid the contract. The basis of condition clause is emerged from common law and also used in insurance law of Iran. This condition in that system after decades that has been criticized faced with notable changes. In this article, the issue, nature and consequences of the basis of contract clause is studied, not to use such expressions and conditions in proposal forms but insurance contract is suggested since it leads to injustice against the insured.
\end{abstract}

Keywords: insurance contract, material facts, principle of good faith, basis of contract clause

\section{Introduction}

An insurance contract is a contract based on the principle of good faith and this principle should be observed by either party. Since the insurer evaluates the risk of insurance on the basis of the applicant and at the end accepts or rejects it, and naturally the insured has some information that awareness of it is not possible for an insurer and it is required the insured provide him the information, in the way that the insurer assesses the risk and determines the appropriate premium if he wants to take the risk.

If the utmost good faith not be observed by the insured, the contract may be avoided by the insurer. By governing the principle of good faith on the relation of the parties, the concern of insurer is reduced about not correct presentation of risk by insured and sufficient sanction for its breach is given to insurer. But it is common that insurers not satisfied to law remedies and included the provisions in the contracts and proposal form to be guaranteed their rights more. These clauses as said above are called "basis of contract clause" by which the insured guarantees the accuracy of the information presented and agrees that this information be placed the basis of contract. If inaccuracy of this information is confirmed later, the insurer has the right to avoid the contract and need not return any of the premiums paid.

Today, due to the extensive knowledge of insurer as an expert beside the insurer doesn't need to special support as past and on the other hand, the need to support of insured as a non-specialist and consumer, and the adequacy of the enforcement of the principle of good faith, the inserting of basis of contract clause in insurance contracts not only is not necessary but also leads to injustice against the insured. Besides, it is worth other countries such as Iran nullify this clause comply with the UK insurance law and prohibit its inserting in insurance contracts. In the following, this clause will be investigated. 


\section{Background of Clause}

The prevalence of this clause since the eighteenth century began in England and it was used in policies, but in this century, there were a few cases that the insurer based on this issue wants to release himself from responsibility and although in these policies, the mentioned clauses were used, but some issues were raised in those cases that considered material facts and the need to invoke the "basis of contract clause" was not felt necessary or at least insurers not considered necessary such a citation. For example, in the case" Bean v. Stupart (1778) and "De Hahn v. Hartley (1786)", the dispute was related to the number of men on board ship, a fact clearly relevant to the possibility of capture, one of the risks insured against. It seems in this century, the first case in which commented what is warranted (warranty) need to be observed carefully. Another case is "Ross v. Bradshaw (1761)", which in this case, Mr. James Ross receives a life insurance for one year that starts from October 22, 1759 and he warranted this fact that he is in good health. But in fact, he was injured in the clash of La feldt in 1747 which had occasioned a partial relaxation or palsy, so that he could not retain his urine or faeces. Evidence was given by several witnesses that the consequences of Sir James's wound were only "inconvenient" and "not dangerous to his life at the time of the insurance". But ultimately the argument based on the basis of condition clause was not accepted (Hasson, 1971, 30-31).

\section{The Nature of Clause}

"Basis of contract clause" in insurance law, in England law and in general in common law has a different nature than other clauses and it is different with what is known in the law of Iran as "Tabani clause". In common law, contractual clauses are divided into two main categories "condition" and "warranty". If a "condition" is breached the innocent party is entitled to repudiate the contract and claim damages. But If a "warranty" is breached the innocent party may claim damages, but cannot end the contract (Beatson, et al, 2010, 139-140). Another clause is in the common law system that is known as "innominate terms" and it is a clause that its importance cannot be known in advance to be placed in one of two parts of condition or warranty, but its importance is considered when to be breached. This often applies to a term which is wider in meaning, such as a claim that something is 'in good condition'. This could be breached in a minor way or a very serious way (Charman, 2007, 113). This is a 'wait and see' approach: in other words, the courts look at the effects of the breach on the injured party to determine whether the breach itself was of a condition or a warranty (Fafinski, 2009, 77).

So in contracts law in more detailed, contractual clause are divided to "condition", "warranty" and " innominate terms ". But "warranty" in insurance law has a different concept from "warranty" in the general contract law. Warranty in insurance laws has an effect as "condition" or "important clause" and its breach gives the authority to insurer to release himself from the obligations of contract completely and this matter is not important that what has been breached is very important and effective or not, and the insured cannot invoke the defense that what has been breached is not considered a material fact. In insurance law, warranties are considered the most important term of insurance contract. Breach of warranty brings the entire insurance contract to an end and precludes the policyholder from making a claim as from the date of the breach unless the policy wording prescribes a different consequence (Malcolm, 2010, 14).

For better understanding of basis of contract clause, it is necessary to pay attention to insert these clauses in insurance applications and insurance policies. These clauses will be included in the forms of England insurance as follows:

- "I/We agree that this proposal and declaration and any particulars given separately shall be the basis of the contract between the Insurer and myself/ourselves."

- "The proposal or application and declaration you have completed, and any other information supplied, form the basis of this contract."

These clauses or statements are known as warranty in insurance law: Article 33 of the Marine Insurance Act 1906 in England has provided: "A warranty, in the following sections relating to warranties, means a promissory warranty, that is to say, a warranty by which the assured undertakes that some particular thing shall or shall not be done, or that some condition shall be fulfilled, or whereby he affirms or negatives the existence of a particular state of facts". And further states that a warranty may be express or implied.

\section{Compared with Entire Contract Clause}

One type of clauses that can be included in the contracts and is common in the field of life insurance is the "entire contract clause". This clause may be confused, especially in Iranian law, with the clause of "the basis of contract" or considered as a reflection of the "entire contract clause" (Elsan, 2005, 164). And it is imagined as in the clause of "basis of contract", all previous statements and declarations constitute the basis of contract, based 
on the clause of "entire contract", all these and as the basis of contract clause constitute the integrity of the contract. While in the area of insurance law, these two don't have any similarity and connection with each other. Contractual relationships generally form based on the statements, expectations, behaviors of parties and parties on that basis enters into the contract. Each of the parties may be set their expectations and contractual obligations based on statements, documents and behaviors of the other party and those cases at the time of dispute invoke to these cases that may not be noted them in contract and in another way want to prove them. This causes an uncertainty for each of the parties in the providing and use of evidence, and therefore the fate of the contract. To avoid such uncertainty, they insert "entire contract clause".

The aim of insert entire contract is to express agreement and contract between them is only that thing that is written in the contract and deprives the other party of this claim that statements and announcements in negotiation and before signing the contract are the terms and agreements of a contract (Peden, 2006, 1). An example of indicating the entire contract can be as the following: "This agreement [and list other relevant agreements, if applicable] constitutes the entire agreement between the parties and supersedes and extinguishes all previous drafts, agreements, arrangements and understandings between them, whether written or oral, relating to this subject matter.

So in comparison with the basis of contract clause must be said:

First, the "entire contract clause" is used only in life insurance and in other types of insurance is not used, while the basis of contract clause will be used for all types of insurance contract.

Second, the entire contract clause explicitly excludes other documents that haven't noted them from what may be considered as "Tabani terms in Iran and Islamic law" and only include what has been pointed.

Thirdly, basis of contract clause in insurance law is to support the insurer, while the entire condition clause supports insured.

\section{Breach of Clause}

About the "basis of contract clause", attention to these cases are necessary that first, this clause in insurance law is considered a part of important clauses in countries where classifying the importance of clauses, but in Iranian law which clauses are not rated in terms of importance are a part of contractual clauses. Secondly, importance or unimportance of what its accuracy is validated and guaranteed in the case of confirming its incorrectness, not has any effect on enforcement and in any case, the insurer can repudiate the contract. So by converting pre-contractual statements to the insurance clause, in the case of untrue statements or non-disclosure by the insured, a "basis of contract clause" is added to the means of usual remedy of insurers.

It is not required that the insurer proves that the information guaranteed are essential and important information and has been effective on his decision as a prudent insurer in accepting the risk or determining the premiums or other conditions of insurance (Soyer, 2001, 160). Breach of a warranty is one of the positive defenses of the insurer. In this respect, it is understandable that law has put the onus to prove breach of warranty on the shoulders of the insurer. It is, however, open to the parties to insert express words to shift the burden of proof.

The Marine Insurance Act also provides that "A warranty, as above defined, is a condition which must be exactly complied with, whether it is materialized to the risk or not. If it is not so complied with, then, subject to any express provision in the policy, the insurer is discharged from liability as from the date of the breach of warranty, but without prejudice to any liability incurred by him before that date" (Article 33(3) of the Marine Insurance Act 1906). So if the information provided is incorrect, the mentioned clause is breached, no matter to what extent this information has been material. Breach the clause deprives the insured from the right of receiving compensation (Airmic Technical, 2013, 5).

Thus, where an applicant for life insurance declared that she didn't have any 'operation' when, in fact, she had given birth to a child by Caesarian section, the insurance company was held to be entitled to avoid the policy on the ground that there was a breach of a condition precedent to the company's liability (Beatson, 2010, 336).

In Iranian law, unlike England law, there is no legal provision as in Article 33 of the Marine Insurance Act that insured approves or denies the existence of circumstances and then that its contrary is proved on the basis of "warranty", the insurer has the right to avoid the contract. However, this clause can be seen in the general conditions of different insurance companies in Iran $^{1}$. Article 12 of the Insurance Act 1937 of Iran provides: "When the insured refrains intentionally from saying statements or deliberately make incorrect statements and undeclared material or incorrect statements be such that changes the issue of risk or reduces from its importance

\footnotetext{
${ }^{1}$ Iran Insurance Company General Terms and Asia Insurance Company General Terms. Article 1
} 
in terms of the insurer, the insurance contract will be void even if the mentioned stages not have any effect on the incident. In this case, not only the premium is not refundable but the insurer has the right to demand premium from the insured to date that is overdue."

Therefore, the provisions of Article 12 of the Insurance Act differ from Article 33 of the Law of Marine Insurance of England, and hence Iranian insurers will not be able to use Article 12 of the Insurance Act as much as English insurers have used Article 33 based on the basis on contract. Because such legal regulation doesn't exist in Iran Insurance Regulations if the inaccuracy of statements be clear that an insurer has stated based on the "basis of contract" be possible to consider the insurance contract void. And therefore the insurer is inevitable to rely on general regulations of contracts that the regulations may fail to provide such sanction i.e. the nullity of the insurance contract. But according to the general rules of insurance contracts of other countries such as England, might provide such target for the insurer but as mentioned above this issue faced with change and lost its effectiveness. However, the inclusion of such provisions in the insurance proposal forms has an important effect for the insurer and shift the burden of proof in favour of the insurer (Soyer, 2001, 164; Khorooshi, 2011, 214).

\section{Review of Basis of Contract Clause}

In common law apart from exceptional cases, a necessary attention has not been on the clauses of insurance contracts (Hasson, 1984, 517). But the inclusion of basis of contract clause has always been criticized and such clauses can lead to inequities in favor of the insurer because only based on a contractual mechanism gives right to insurer to avoid the contract without what has been breached to be a material fact; And even if the insurer knew the truth of the matter when signing contract do not pay attention to that and the contract was signed, but later this issue is considered a way for avoiding contract with the use of a contractual tool.

Lord Greene MR described them as 'particularly vicious' and 'mere traps' which should be construed strictly. (Beatson, et al, op.cit, 336). In 1908, Lord Justice Fletcher Moulton said he wished he could "adequately warn the public against such practices" (The Law Commission, 2014, 10). ${ }^{2}$

Law Commission of England and Scotland in 1980 declares his disagreement with such clauses and expresses that such clauses should not be considered. In 2009, in his other report emphasized to this issue and suggest amending the law in this regard. In 2012 in accordance with Consumer Insurance (Disclosure and Representations) Act 2012 which on 6th April 2013 came into force, this suggestion was accepted. Article 6(2) provides that: "Such a representation is not capable of being converted into a warranty by means of any provision of the consumer insurance contract (or of the terms of the variation), or of any other contract (and whether by declaring the representation to form the basis of the contract or otherwise)."

After Consumer Insurance (Disclosure and Representations) Act 2012, in a case ${ }^{3}$ a British Appeal court accepted theory of basis of contract clause in Commercial Insurances. Therefore, despite the fact that the basis of contract clauses is criticized by lawyers and judges, the recent case shows that the basis of the contract clause in commercial insurances is still considered valid. But it was criticized because there wasn't a logical explanation about the boundaries between commercial and non-commercial insurances. Abolishment the basis of contract clause is a subject in all types of insurances is proposed by the Law Commission in 2009 and 2014. Finally, in 2015 this subject is accepted by "Insurance Act 2015" in Article 9 in commercial insurance.

In the Iranian law, use such clauses in insurance contracts, in lack of a specific law, can be subject to general rules of insurance contracts and general law of contracts and can faced with the same problems and injustices that was investigated in England law. To avoid injustice, it is worth to avoid from inserting such clauses and broad interpretation in order to support insureds. In England, while Consumer Insurance (Disclosure and Representations) Act 2012 not prohibited insurers from using such clauses about Commercial Insurances (before the Insurance Act 2015) at the same time, "Association of Insurance and risk Managers in Industry and Commerce" (Airmic) has advised to insurers to reconsider in their contracts and remove these clauses from their contracts. Since Insurers maintain a strong position under English law without the need for basis clauses, not least because of the draconian remedy of avoidance for material non-disclosure. (Airmic Technical, Op. Cit., 10) The fact is that the principle of good faith and its sanctions against untrue statements of insured gives a sufficient guarantee to insurers and if the insured breach the principle, he will be faced with hard sanctions.

On the other hand it must be said that the purpose of providing such clauses and statements in an insurance policy is nothing other than attracting attention of insured to this issue that what is expressed has a great

\footnotetext{
${ }^{2}$ Joel v Law Union and Crown Insurance Co [1908] available at: http://www.uniset.ca/other/cs3/19082KB863.html

${ }^{3}$ Genesis Housing Association Ltd v Liberty Syndicate Management Ltd [4.10.13]7 November 2013.
} 
importance to pay attention and effort about the accurate disclosure of the facts. So its reasonable goal is "advise" the insured to the "importance" of his statements. Although insurers actually use it by another way and thereby not only they take away the burden of proof on the importance of non-disclosed issues from their shoulders, but also proving its unimportance from the insured is futile, because the insurer will not consider himself responsible based on the breach of contractual clause. Obviously, this use of insurer can never be the purpose of this clause, but it will be contrary to the purpose of insurance, which is to provide insurance cover and protect insured and his invest. And therefore, the logical target of basis of contract clause is to "advise" the insured to the "importance" of his statements, the insurer could achieve this goal in another way, such as in the insurance proposal form with clear terms and highlighted text and mention emphasis phrases pointed out the importance of his statements to him and remind him that false statements could place the insurance policy at the risk of invalidity.

It is possible to be said in maintaining the basis of contract clause: it is a necessary evil because the difficult task of determining material and immaterial facts takes away from the courts. For example:

- The proposal of life insurance of applicant has already been rejected by other insurers and the insured has not disclosed this issue, is it considered important? ${ }^{4}$

- In theft insurance, is this issue considered important that the insured within fourteen ${ }^{5}$ or twenty ${ }^{6}$ years has had a criminal conviction? (Hasson, 1971, 39).

While responding to issues like these cases are not easy, but not impossible to achieve. Of course, insurers cannot claim that the courts in proving material facts use a very difficult criterion, but in fact it can be said that today proves crucial issues for insurers is very easy since the situation of many insurance issues is identified in the judicial precedent. In addition, regardless of all these conversations, today not only a basis of contract clause is prohibited by legislators, but even the "duty to disclosure" which is the main task of the insured is also becoming obsolete by new duty such as the duty to "fair representation" (Insurance Act 2015, Article 3).

In Iran, In "compulsory insurance bill of civil liability of owners of motor vehicles against the third party", that in 2014 from the government to amend the law 2008 had been submitted to parliament, in one of the latest changes that reported in 2015, it was predicted "If it turns out the owner of the vehicle when enter into insurance contract has stated the false statement, the insurer can demand up to ten times the premium from the owner. However, in the event of an accident, the insurer is obligated to pay all the damages according to the law" (Article 8.2). We can see that the only sanction of untrue statements the premiums is manifold as compensation, but insurance policy doesn't invalidate and insurer in any case subject to compensate.

It should be noted, even if this provision were retained could not be a sign of promising to change the approach on how to set up insurance contracts its sanctions. Because this is a special law, as well as it is about a "compulsory insurance". This means that unlike other insurances, the insurer cannot reject the proposal because of high risk or any other reason, while in other insurances, accepting risk and singing contract of insurance with the applicant is from insurer's authorities. So it is only because of the specific nature of this type of insurance and it should not be seen as a sign of growing thinking and positive development in other insurances.

In the "law of compulsory insurance for damages to third parties as a result of accidents caused by vehicles" enacted in 2016 while the legislator not comments to such clause, but of Article 11 which provides: "Inserting any clause in the insurance policy that for an insured or injured party provides lower benefits from the advantages stipulated in this law, or inserting a suspension clause of the obligations of an insurer in contract in any way is null and void." It can be understood that since the "basis of contract clause" can be a clause which not only provides lower benefits from the advantages stipulated in this law for insured and suffered, but generally can cause the irresponsibility of the insurer should be void. Also, this comparison can be carried out with prohibition concerning the "suspension clause" contained in this Article mentioned and concluded rejection on the basis of contract clause on compulsory insurance of vehicles. But it is worth about other insurances that Iranian legislator prohibits insurers from the insertion of such clauses mentioned above, and consider this issue in "commercial insurance bill" that is prepared to amend and replace of the Insurance Act 1937.

\footnotetext{
${ }^{4}$ London Assurance V. Mansel (1879) 11 Ch. D. 363. [It was stipulated that this fact is considered material].

${ }^{5}$ Schoolman v. Hall [1951] 1 Lloyd's Rep. 139(C.A.). [It was stipulated that this fact is considered material].

${ }^{6}$ Regina Fur Go. v. Bossom. [1957] 2 Lloyd's Rep. 466 affirmed by the Court of Appeal [1958] 2 Lloyd's Rep. 425. [It was stipulated that this fact is considered material].

7 "Commercial Insurance bill" on the suggestion of the Ministry of Economic Affairs and Finance dated 2005 passed by the Council of Ministers and submitted to Parliament.
} 


\section{Conclusion}

An insurance contract is a contract based on utmost good faith. Since the insurer must accept a risk that not has sufficient knowledge and information about it or maybe access to this information is not possible for him, it is asked the insured to properly introduce risk to him to assess risk based on the insured information and decide on its acceptance or required premium, hence the necessity of observing the good faith principle from the insured is felt more. And to contractual balance, a heavy sanction for breaching the obligation is intended. But it is common that insurers not satisfied to good faith sanction and to further guarantee of their rights as well as relief from the burden of proving some issues, ask the insured to confirm correctness of announcements and their replies and stipulate that these replies and announcements form the basis of the contract clause. If later the incorrectness of these announcements is proved, the insurer regardless its materiality can avoid the contract. It was always criticized by lawyers and even judges. finally, under the Consumer Insurance (Disclosure and Representations) Act 2012 the insurers were prohibited from its applying in non-commercial insurances and subsequently about other insurance contracts under the "Insurance Act 2015" was applied this limitation. Before the recent enactment, Association of Insurance and Risk Managers in Industry and Commerce of England asked the insurers to refrain of inserting such clauses in all insurances.

Iranian insurers also use such clauses in proposal forms and contracts of insurance, which can lead to injustice and enjoying contrary to the purpose of insurance. Hence it is recommended that legislator prevents insurers from insertion of such provisions and clauses, and courts until to the enactment of a binding regulation try to strict interpretation and its limited applying.

\section{References}

Airmic Technical. (2013). Basis Clause, A practical guide to basis clauses in insurance contracts. Herbert Smith Freehills.

Beatson, S. J., Andrew, B., \& Cartwright, J. (2010). Anson 'slaw of contract (29th ed.). oxford university press, New York. https://doi.org/10.1093/he/9780199282470.001.0001

Charman, M. (2007). Contract Law (4th ed.). Willan Publishing, Devon.

Elsan, M. (2005). duty to good faith in life insurance, legal research, no 8, Tehran.

Fafinski Stefan, F. E. (2009). Contract Law. Pearson Education Limited, Essex, UK.

Genesis Housing Association Ltd v Liberty Syndicate Management Ltd [4.10.13]7 November. (2013). Retrieved November 24, 2015, from http://www.kennedyslaw.com/casereview/GenesisHousingAssociation/Accessed25-jun-2014

Hasson, R. (1971). The Basis of The Contract Clause In Insurance Law. The Modern Law Review, 34(1). https://doi.org/10.1111/j.1468-2230.1971.tb02310.x

Hasson, R. (1984). The special nature of insurance contracts: a comparison of the American and English law of insurance. Modern Law Review, 47(5). https://doi.org/10.1111/j.1468-2230.1984.tb01663.x

Joel v Law Union and Crown Insurance Co. (1908). Retrieved November 27, 2015, from http://www.uniset.ca/other/cs3/19082KB863.html

Khorooshi, A. (2011). Insurance Law, Obligations in Indemnity Insurance (1st ed.). Majd publication, Tehran.

Malcolm, H. et al. (2010). Property Insurance Law and Claims (1st ed.). Witherby Insurance and Legal, Edinburgh.

Peden Elisabeth, J. C. (2006). Entire Agreement and Similar Clauses. Journal of Contract Law, 22(1), Sydney Law School.

Soyer, B. (2001). Warranties in Marine Insurance (1st ed.). Cavendish Publishing Limited, London.

The Law Commission and the Scottish Law Commission. (2014). Insurance Contract Law: Business Disclosure; Warranties; Insurer's Remedies for Fraudulent Claims; and Late Payment, law com no 353 - scot law com no 238 .

\section{Copyrights}

Copyright for this article is retained by the author(s), with first publication rights granted to the journal.

This is an open-access article distributed under the terms and conditions of the Creative Commons Attribution license (http://creativecommons.org/licenses/by/4.0/). 